\title{
Amblyomma birmitum a new species of hard tick in Burmese amber
}

\author{
LIDIA CHITIMIA-DOBLER ${ }^{1}$, BRUNO CANCIAN DE ARAUJO ${ }^{2}$, \\ BERNHARD RUTHENSTEINER ${ }^{2}$, TIMO PFEFFER ${ }^{3}$ and JASON A. DUNLOP ${ }^{4}$ \\ ${ }^{1}$ Bundeswehr Institute of Microbiology, Neuherbergstrasse 11, D-80937 Munich, Germany; German Center of Infection \\ Research (DZIF) Partner Munich \\ ${ }^{2}$ Zoologischer Staatssammlung München Münchhausenstrasse 21, D-81247, Munich, Germany \\ ${ }^{3}$ Keyence Deutschland GmbH, Siemensstrasse 1, 63263 Neu-Isenburg, Germany \\ ${ }^{4}$ Museum für Naturkunde, Leibniz Institute for Evolution and Biodiversity Science, Invalidenstrasse 43, D-10115 Berlin, \\ Germany
}

(Received 24 March 2017; revised 4 May 2017; accepted 9 May 2017; first published online 6 Fune 2017)

SUMMARY

Amblyomma birmitum sp. nov. is formally described as a new record from 99 Ma old Burmese amber from Myanmar. This confirms the presence of the extant hard tick genus Amblyomma C.L. Koch, 1844 (Ixodida: Ixodidae) in the Late Cretaceous. This discovery is placed in its wider context and some reports of fossil hard ticks, such as a Hyalomma C.L. Koch, 1844 in Eocene Baltic amber, are misidentifications. The genus Amblyomma belongs to the clade Metastriata, a group which probably also accommodates two extinct genera, Cornupalpatum Poinar and Brown, 2003 and Compluriscutata Poinar and Buckley, 2008, also found in Burmese amber. All three fossils are thus only a little younger than published molecular divergence time estimates (ca. $124 \pm 17 \mathrm{Ma}$ ) for the Metastriata lineage. Amblyomma has a largely Gondwanan distribution today. However, in some biogeographical scenarios, e.g. the Samafrica model, its predicted radiation time postdates the dissolution of the original Gondwana supercontinent raising questions about how its current distribution pattern was achieved.

Key words: Cretaceous, fossil, Amblyomma, Ixodidae, biogeography, Gondwana, Samafrica.

\section{INTRODUCTION}

Ticks (Arachnida: Parasitiformes: Ixodida) are a well-known group of haematophagous ectoparasites with about 900 living species (Guglielmone et al. 2014). Several are of considerable economic importance as vectors for viral and bacterial infections, affecting both humans and domestic animals. A summary of tick biology can be found in Sonenshine and Roe (2013) and a list of valid names in Guglielmone and Nava (2014). Given that ticks are parasitic on terrestrial vertebrates, there are interesting questions about when (and where) they first evolved and who their original hosts were; see e.g. Black and Piesman (1994) or de la Fuente (2003), as well as the Discussion section below. The tick fossil record is sparse. Dermacentor reticulatus (Fabricius, 1794) and Ixodes sigelos Keirans et al. 1976 are living species recorded as subfossils (Kulczyński in Schille, 1916; Sanchez et al. 2010). Records of Amblyomma Koch, 1844 which are almost indistinguishable from the living species Amblyomma argentinae Neumann, 1905 and Amblyomma dissimile C. L. Koch, 1844 were found

* Corresponding author: Museum für Naturkunde, Leibniz Institute for Evolution and Biodiversity Science, Invalidenstrasse 43, D-10115 Berlin, Germany. E-mail: jason.dunlop@mfn-berlin.de in Miocene (ca. $16 \mathrm{Ma}$ ) Dominican Republic amber (Lane and Poinar, 1986; Keirans et al. 2002). The argasid tick Ornithodoros antiquus Poinar, 1995 also comes from Dominican amber. Ixodes succineus Weidner, 1964 from the Eocene (ca. 44-49 Ma) Baltic amber in northern Europe was redescribed by Dunlop et al. (2016) and assigned to the modern Ixodes subgenus Partipalpiger Hoogstraal et al. 1973, whose members are geographically restricted to Asia nowadays. The argasid tick Carios jerseyi Klompen and Grimaldi, 2001 comes from Cretaceous (ca. 90-94 Ma) New Jersey amber from the USA. Finally, two tick species, Cornupalpatum burmanicum Poinar and Brown, 2003 and Compluriscutata vetulum Poinar and Buckley, 2008, were formally described in Burmese amber from Myanmar, representing the thus far oldest records from the Cretaceous (ca. $99 \mathrm{Ma}$ ). Both were assigned to extinct genera.

Burmese amber also hosts a provisional record of the genus Amblyomma by Klompen in Grimaldi et al. (2002). This is significant as it is the oldest putative example of a tick genus with species still living today. Here, we confirm the presence of an Amblyomma tick in Burmese amber based on a new specimen, which we formally describe as a new species and compare it to its living representatives and their patterns of distribution. 


\section{MATERIALS AND METHODS}

The type and only known specimen comes from the Jörg Wunderlich collection and bears the inventory number F24671 BN/CJW. His material will probably later be deposited in the Senckenberg Museum Frankfurt/Main (J. Wunderlich, personal communication). Most Burmese amber comes from the Hukawng Valley in northern Myanmar. It is currently dated to the Late Cretaceous (lowermost Cenomanian) with an absolute age of ca. $99 \mathrm{Ma}$ (Shi et al. 2012). In other words, it is very close to the boundary between the Early and Late Cretaceous.

\section{Imaging}

The images for focus stacking were taken using a Leica Z16 APO, driven and controlled by a Cognisys Stackshot macro rail system. The lighting system used was a 12 channel light-emitting diode (LED) system developed by one of the authors (Bruno Cancian de Araujo) and composed of 300 super bright LEDs. The system works with direct light diffused by a central tube made with a photographic filter (Lee filters, model 129). The stack images were combined using the software Helicon Focus 6·7·1. A Keyence VHX-5000 Digital Microscope with a tiltable stand and a combination of upper light and transmitted light for focus stacking was used. We partly used polarized light for more details.

\section{Micro $C T$}

For X-ray microCT scanning the piece of amber containing the specimen was fixed on a glass stub with a clamp formed of Styrofoam. Scanning was performed with a Phoenix Nanotome m (GE Measurement and Control, phoenix|x-ray, Wunstorf, Germany). The 1440 projections ( 3 averaged, 1 skipped, total duration $48 \mathrm{~min}$ ) were taken at a current of $100 \mathrm{kV}$ and $100 \mathrm{~mA}$ using a molybdenum target. Voxel resolution of the resulting dataset was $3.42472 \mu \mathrm{m}$. Initially, the dataset was cropped and converted to 8 bit (by adjustment of the histogram) with the help of the software VG Studio Max 2.3 (volume Graphics, Heidelberg, Germany). The noise was reduced with VG Studio Max or Amira 6.0.1 (FEI, Hillsboro, OR, USA). The data were visualized by volume rendering with VG Studio Max (Phong Volume renderer), Drishti 2.6.2 (Limaye, 2012, https://github.com/nci/drishti).

\section{SYSTEMATIC PALAEONTOLOGY}

\section{Ixodida Leach, 1815}

Amblyomma C.L. Koch, 1844

Amblyomma birmitum sp. nov.

Etymology: From Burmite, the original name of this fossil resin used in the first description by Helm (1894).

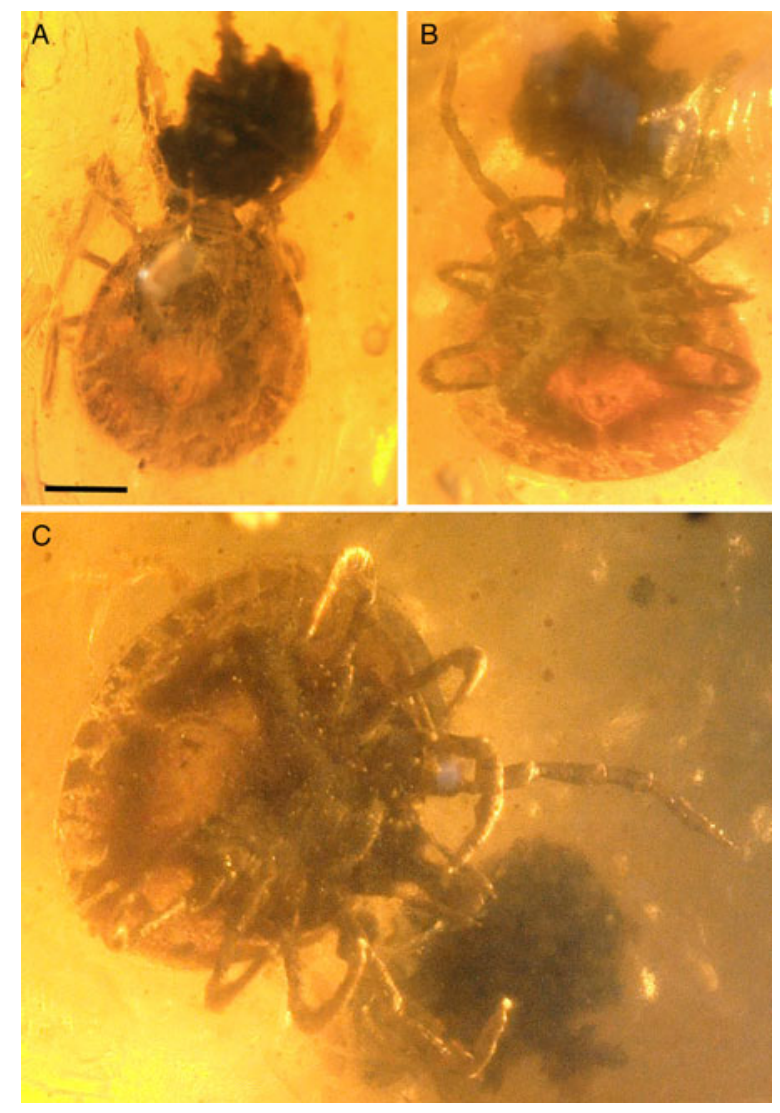

Fig. 1. Holotype of Amblyomma birmitum sp. nov., Jörg Wunderlich collection no. F24671BN/CJW, from Late Cretaceous (ca. $99 \mathrm{Ma}$ ) Burmese amber from Myanmar. Overview in (A) dorsal, (B) ventral and $(\mathrm{C})$ ventraloblique view.

Material: Holotype and only known specimen, Jörg Wunderlich collection no. F24671BN/CJW, Burmese amber, Myanmar, Late Cretaceous (Cenomanian).

Diagnosis: Body subcircular, scutum heartshaped, the second article of palps is at least twice as long as third article, 11 festoons, eyes present, spiracle plates comma-shaped, coxae I-IV with no obvious spurs.

Description: Unengorged female (Fig. 1A-C). Idiosoma: Ornamentation indistinct; body subcircular; length (excluding capitulum) $1569 \mu \mathrm{m}$, greatest width $1591 \mu \mathrm{m}$; scutum $849 \mu \mathrm{m}$ (measured in the middle of the scutum, and $732 \mu \mathrm{m}$ from the scapula to the edge) in length; maximum width $1026 \mu \mathrm{m}$, heart-shaped, punctuations rare, deep and medium-sized, distributed irregularly, sides are straight and posterior angle broad; scapulae rounded and short; cervical grooves short and deep; eyes small and distinctly convex located around level of leg II; eleven festoons ranging in basal width from 153 to $156 \mu \mathrm{m}$ and 144 to $149 \mu \mathrm{m}$ length (Fig. 1B and C); anus located $456 \mu \mathrm{m}$ from posterior border; anal groove $\mathrm{Y}$-shaped with lateral branches reaching upper margin of anus and the 
Y-tail extending to the sixth festoon; genital aperture subcircular in form, situated between coxa III-IV; spiracle plates comma-shaped, medial and lateral margins parallel, posterior margin slightly convex, dorsal prolongation long, broad, perpendicular to the anterior-posterior axis, macula, round, situated subterminally.

Capitulum: Length from apices to the posterior margin of basis $671 \mu \mathrm{m}$; basis capituli subtriangular posterior margin almost straight, lateral margins round, cornua absent, ventrally posterior margin straight, length from palpal insertion to posterior margin of basis $428 \mu \mathrm{m}$, width $228 \mu \mathrm{m}$; palps cylindrical, with length of four segments as follows; segment 1, $46 \mu \mathrm{m}$; segment 2, $266 \mu \mathrm{m}$; segment 3, $139 \mu \mathrm{m}$; segment 4, $56 \mu \mathrm{m}$; visible dorsally and ventrally and no setae observed; hypostome length 537 $\mu \mathrm{m}$, width at base $177 \mu \mathrm{m}$; columns of teeth on hypostome are $2+2$ blunt-tipped teeth on the anterior half; apical corona not observed; porose areas oval, diameter of one area $122 \mu \mathrm{m}$ length, $62 \mu \mathrm{m}$ width, slightly depressed, length in horizontal position.

Legs: Coxae I-IV with no obvious spurs; tarsus I tapering distally, length $455 \mu \mathrm{m}$, clear, oval area on the dorsum of tarsi I is Haller's organ; claws paired, slender, simple, slightly curved; with distinct pulvillus on all legs. Chaetotaxy: Marginal setae observed. On the ventral side, small setae and two setae on each leg joint were observed.

\section{DISCUSSION}

The presence of eyes in the new fossil (Fig. 2A and B) excludes the previously described Burmese amber tick species. Both $C$. burmanicum and $C$. vetulum were described as eyeless (or at least eyes were not detected). Additionally, C. burmanicum differs from our new fossil in that it does not have an elongate second pedipalp article and has a unique extra claw on the penultimate (third) pedipalp article (Poinar and Brown, 2003: Figs 3 and 4). The pedipalp of $C$. vetulum is closer to that seen in our new fossil, but this species has 13 festoons along the posterior margin of the idiosoma (Poinar and Buckley, 2008: Fig. 3). Our new specimen (and C. burmanicum) has only 11 festoons (Fig. 2A and B). We are therefore confident that at least three distinct species of hard tick were present in the Burmese amber forest.

In the new fossil, the hypostome tooth columns have a $2 / 2$ arrangement, albeit only in the anterior half (Fig. 2E). The hypostome teeth are not easy to resolve, but can be recognized as a total of four rows of sharp, triangular and backwards-pointing projections emerging along the length of the hypostome. All modern Asian, African and Neotropical Amblyomma adults have a $3 / 3$ or $4 / 4$ tooth arrangement, or even $5 / 5$ in Amblyomma clypeolatum Neumann, 1899 females (Voltzit and Keirans,
2002, 2003; Voltzit, 2007). In this respect, our new fossil resembles the Recent Australian species Bothriocroton auruginans (Schulze, 1936), although here the 2/2 teeth are distributed along the whole length of the hypostome. The new fossil differs from other Amblyomma species coming from the former Gondwana region in that the genital aperture is located between coxa III-IV (Fig. 1C). In the other species it is located between coxae II and III or between coxae II (Voltzit and Keirans, 2002, 2003), except in three Neotropical Amblyomma species which have the genital aperture between coxae III - namely Amblyomma cruciferum Neumann, 1901, Amblyomma darwini Hirst and Hirst, 1910 and Amblyomma humerale C.L. Koch, 1844 (Voltzit, 2007) - and no coxal spurs. The position of the eyes is close to the condition seen in, e.g. Amblyomma variegatum Fabricius, 1794 or Amblyomma pomposum Dönitz, 1909. We should also note that the fourth segment of the palps is very long (Fig. 1B and C) compared with recent Amblyomma species and, in this sense, it is similar to the condition in one of the other amber species C. vetulum. Adults of most Amblyomma species are medium- or large-sized ticks in which the second article of the palp is at least twice as long as the third article. The scutum is usually ornamented with varying-colour iridescent patterns. Eyes are present and in most species are not positioned in sockets (Nicholson et al. 2009).

\section{Biology of Amblyomma}

Following Klompen et al. (2002) the genus Aponomma Neumann, 1899 is now considered a synonym of Amblyomma, which is represented today by 132 valid, extant species (Guglielmone and Nava, 2014). In detail, Klompen et al. (2002) transferred some of the Aponomma species from the indigenous Australian Aponomma to Bothriocroton Keirans et al., 1994 and the remaining Aponomma species to Amblyomma. The genus Amblyomma is thus currently distributed in all six zoogeographic regions (Guglielmone et al. 2014), although we should stress that $98 \%$ of them occur exclusively or non-exclusively in territories that originally constituted Gondwana. By contrast, only three species are exclusively found in the Neartic region (Guglielmone et al. 2014), which was originally part of Laurasia. Typical hosts of Amblyomma today include lizards and snakes (Squamata) as well as tortoises (Testudines) which form the principal host for several species. In fact, Amblyomma as a group utilizes a wide range of hosts, which is different from the situation in other genera of Ixodidae (Guglielmone et al. 2014). Our new taxon in Burmese amber confirms the presence (see also Grimaldi et al. 2002) of Amblyomma in the Cretaceous of Southeast Asia. It is only the third 
A

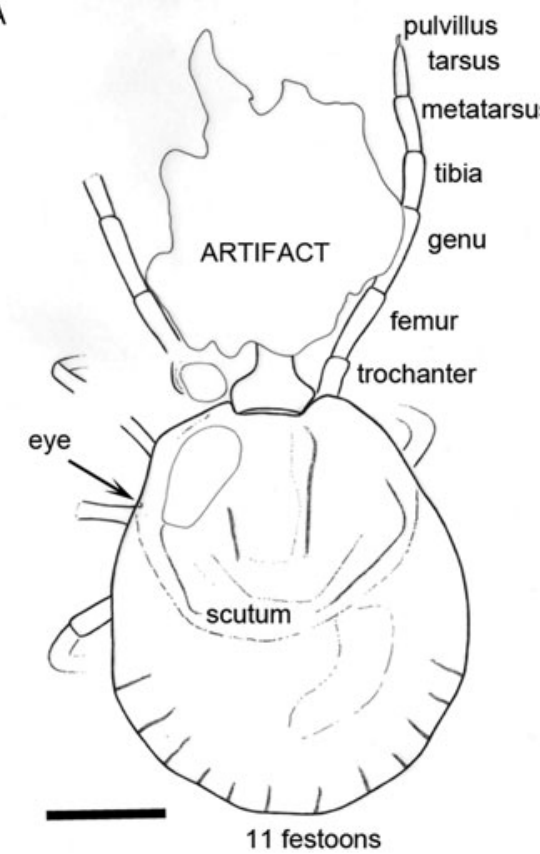

B

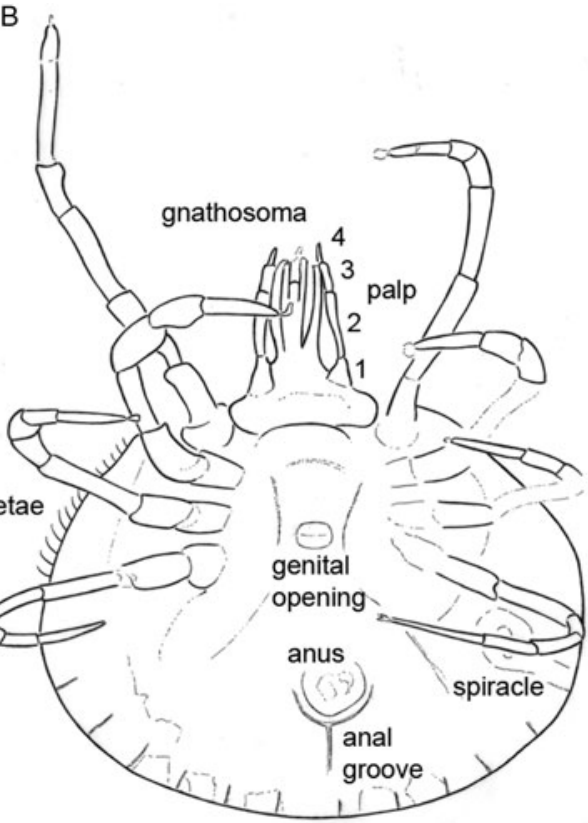

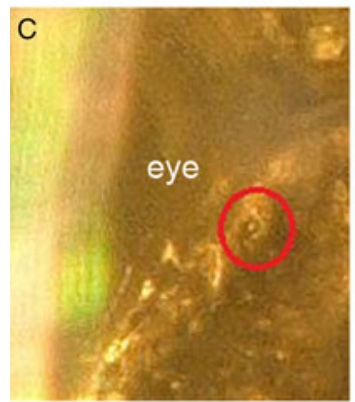

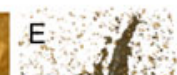

hypostome with $2+2$ tooth columns on the anterior half
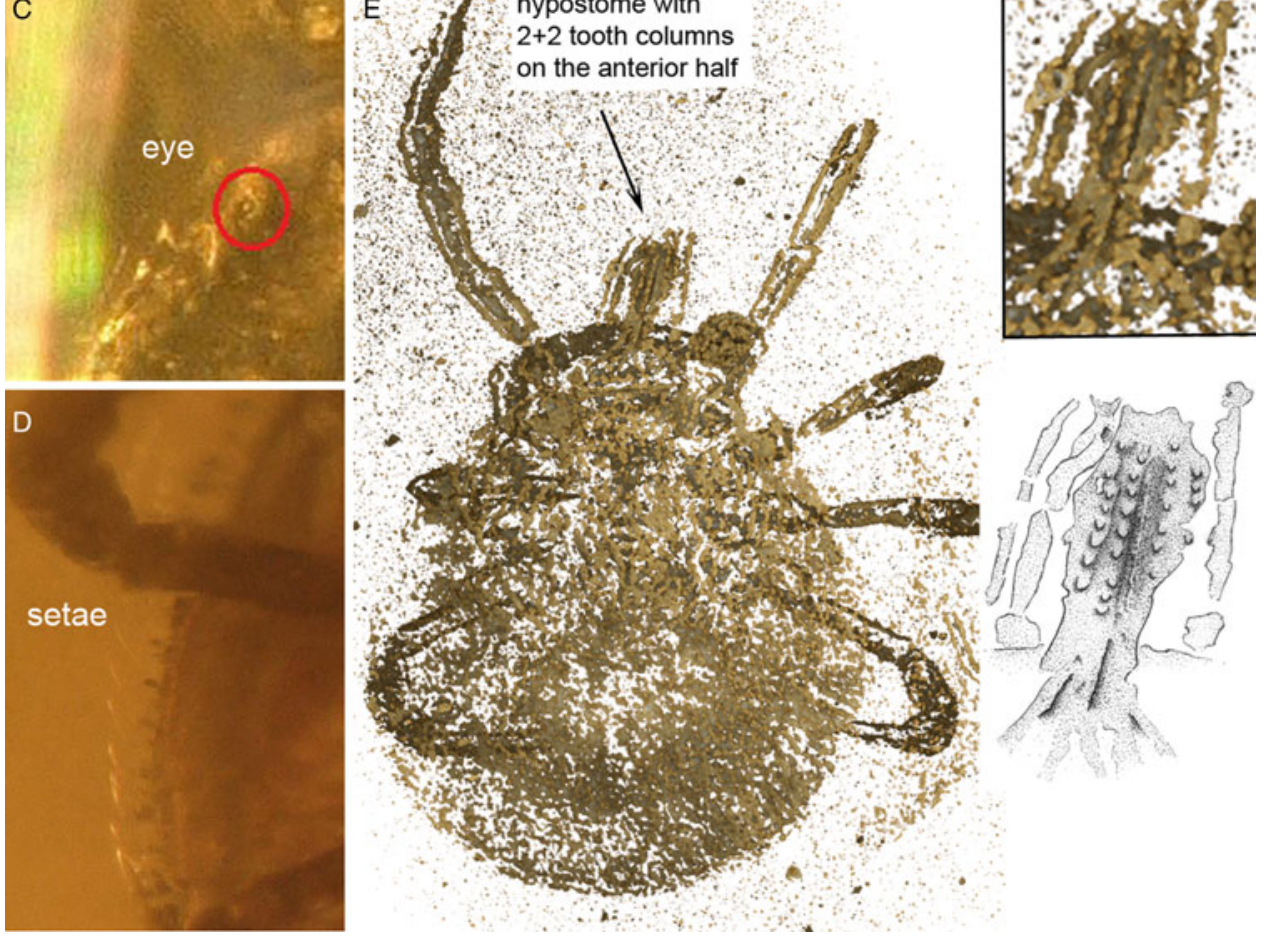

Fig. 2. Holotype of Amblyomma birmitum sp. nov., Jörg Wunderlich collection no. F24671BN/CJW, from Late Cretaceous (ca. $99 \mathrm{Ma}$ ) Burmese amber from Myanmar. (A) Drawing of the dorsal face showing the leg segments, eye, scutum and festoons. (B) Drawing of the ventral face showing gnathosoma with the palp segments, coxae, genital aperture, stigma, setae and anal groove. (C) Detail of eye (photos with Keyence 5000 Digital Microscope). (D) Focus on setae on the idiosoma side (photos with Keyence 5000 Digital Microscope). (E) Hypostome tooth columns $(2+2$ arrangement), $\mu \mathrm{CT}$ Drishti $2 \cdot 6 \cdot 2$; including insets showing close up and interpretative drawing of the hypostome.

tick species to be described from this deposit and the first to be formally placed in an extant genus. Amblyomma can thus be traced back approximately 99 million years. Together with an opilioacarid mite from the same amber deposit (Dunlop and de Bernardi, 2014), these Cretaceous ticks also represent the oldest records of parasitiform acarids in general.

\section{Phylogeny and divergence times}

With respect to the phylogenetic position of Amblyomma, there is a basic division of hard ticks into the Prostriata group, restricted to the genus Ixodes, and the Metastriata group containing all the other genera (e.g. Black and Piesman, 1994). In 


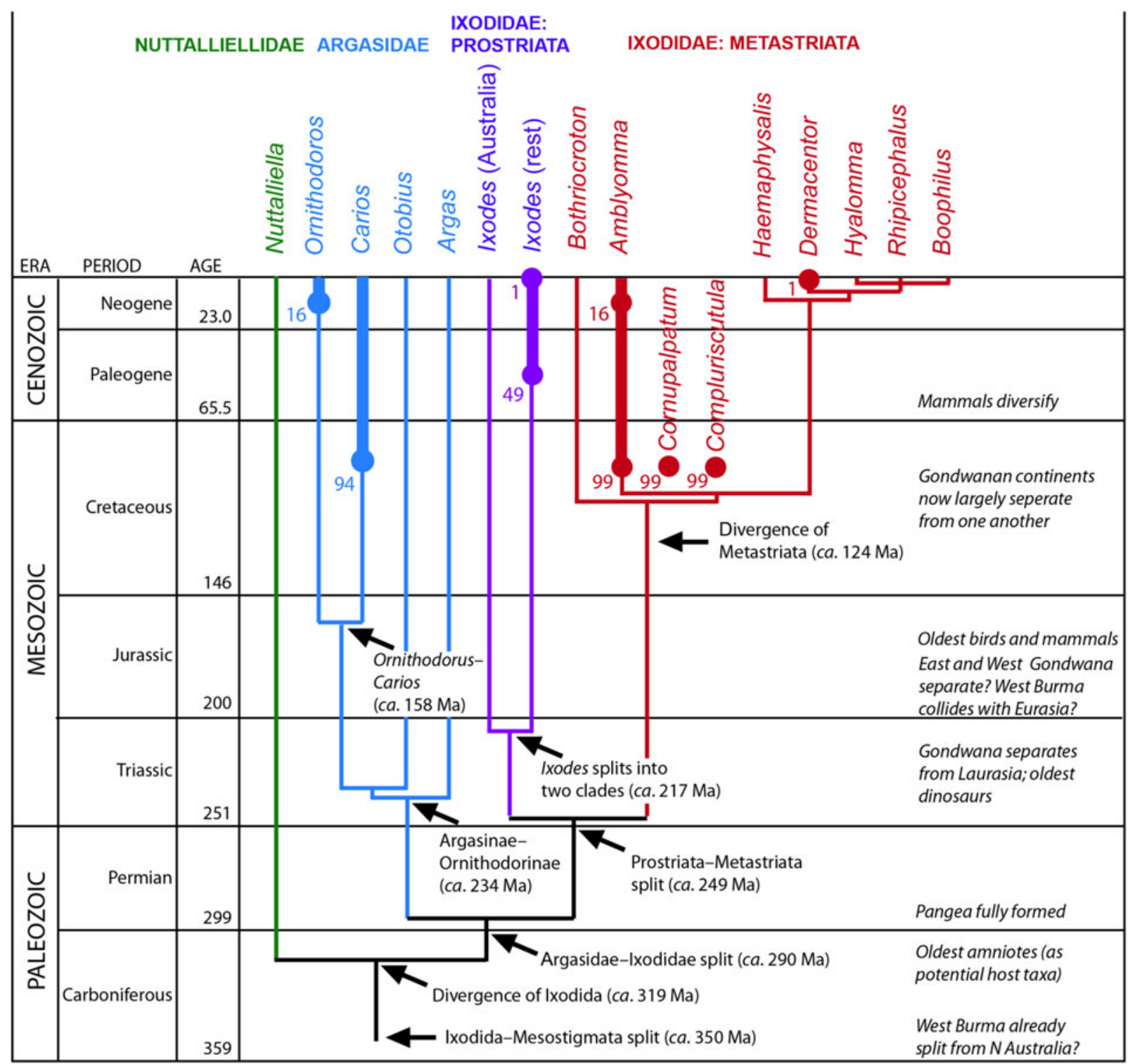

Fig. 3. Phylogenetic tree largely based on Mans et al. (2012) with the fossil record of the main genera superimposed. Circles indicate the known fossil occurrences with their estimated dates in millions of years. The inferred origination dates of the major clades are based on Mans et al. although we should caution that all of them had error bars of about \pm 20 million years. Colour scheme: green (Nuttalliellidae), blue (Argasidae), purple (Ixodidae: Prostriata), red (Ixodidae: Metastriata). Poinar's extinct genera are assumed to be metastriates too, possibly close to Amblyomma (see text for details).

Prostriata the anal groove extends anterior to the anus, while in Metastriata the anal groove is located posterior to the anus (Beati and Keirans, 2001; Nicholson et al. 2009). We should note that for the genus Ixodes most authors now recognize a split between the Australian and non-Australian species, or have even questioned the monophyly of the genus (e.g. Klompen et al. 2000). In overview, Barker and Murrell (2004, Fig. 1) proposed a working hypothesis for hard ticks of the form [Ixodes (Bothriocroton (Amblyomma (Haemaphysalis + Rhipicephalinae and Hyalommine genera)))]. This reflects the older, non-cladistic, scheme of Hoogstraal and Aeschlimann (1982) and the same basic pattern was also recovered in the molecular phylogeny of Mans et al. (2012, Fig. 2) using 18S
rDNA; although other genes gave slightly different results (see their Fig. 3) such as the non-monophyly of Amblyomma.

There are numerous proposals, summarized by de la Fuente (2003, Fig. 8), for when ticks - or specifically hard ticks - are thought to have originated. Most were derived, in part, from the fossil record of their typical modern host species. For example, Hoogstraal (1985) inferred late Palaeozoic or early Mesozoic origins for argasid-like ticks in general, with amblyommid ticks present on reptile hosts as early as the Permian and hyalommine and rhipicephaline tick lineages evolving later on mammalian hosts in the Cretaceous and Cenozoic, respectively. In fact, published inferences on tick origins range from as old as the Devonian (Oliver, 1989; Dobson 
and Barker, 1999), with amphibians as putative hosts, to as young as the Cretaceous (Black and Piesman, 1994; Nava et al. 2009): a difference of almost 300 million years! Klompen et al. (1996) also criticized the assumption that tick phylogeny is determined by the phylogeny of their hosts; i.e. that the early derivative ticks must be those that live on reptiles today. Mans et al. (2012: Table 2) estimated divergence times directly using molecular clock methods. Their results include origins for the entire Ixodida in the late Carboniferous $(319 \pm 23 \mathrm{Ma})$, the family Ixodidae around the Permian-Triassic boundary $(249 \pm 23 \mathrm{Ma})$, and the Metastriata radiating in the Early Cretaceous $(124 \pm 17 \mathrm{Ma})$. Thus the Late Cretaceous Burmese amber records of Amblyomma are not much younger than Mans et al.'s estimated divergence time for metastriate ticks in general. Fossils also constrain the split between Amblyomma and its putative sister-group (i.e. Haemaphysalis + rhipicephalines + hyalommines) to at least $99 \mathrm{Ma}$.

The extinct Burmese amber genera have not been formally integrated into the phylogeny of living taxa. The position of the anal groove is unhelpful here as both $C$. burmanicum and $C$. vetulum were described without an anal groove (Poinar and Brown, 2003; Poinar and Buckley, 2008); or at least none could be resolved in the material available. A better guide is the presence of marginal festoons in these Cretaceous fossils. These structures are absent in the prostriate Ixodes and strongly suggest that the two extinct Burmese genera are also metastriate ticks such as Amblyomma. We should also mention de la Fuente's (2003) observation that C. burmanicum resembles Aponomma (= either Bothriocroton or Amblyomma) and comments in Mans et al. (2012) that these extinct species are probably close to Amblyomma. Transposing the (albeit limited) fossil record of the ticks onto the current phylogenetic hypothesis (Fig. 3, see also Mans et al. Fig. 4) yields a framework evolutionary scenario. Nuttalliellidae lacks a fossil record. Argasidae is known since the Cretaceous but is estimated to have split from Ixodidae in the Permian. Ixodes is known from the Eocene but is predicted to have split from the metastriate lineage in the early Triassic. The modern metastriate genera are inferred to have radiated in the Cretaceous.

\section{Corrections to the tick fossil record}

Origins of the most recently diverged hard tick genera - namely Haemaphysalis, Dermacentor, Hyalomma, Rhipicephalus and Boophilus - were previously constrained to an Eocene divergence date of at least 49 Ma by de la Fuente's (2003: Fig. 6) report of a Hyalomma sp. from Baltic amber. However, during the preparation of the present manuscript, it was pointed out to us (Ekaterina Sidorchuk, personal communication) that de la Fuente's amber fossil is not a tick. In fact, it is a rake-legged mite (Acariformes: Caeculidae), a fact clearly indicated by the large inward-facing spines on the forelegs which are very typical for this group of predatory mites and not seen in Hyalomma or any other tick genus. de la Fuente's (2003) paper contains a further misidentification (Ekaterina Sidorchuk, personal communication). The soft ticks figured from Miocene Dominican amber (Fig. 7) are large parasitengonids. It may also be necessary to further check the identity of the larval Ixodes from Baltic amber (de la Fuente, 2003: Fig. 1) and larval ticks from Miocene Dominican amber (his Fig. 4), but this is difficult from the photographs and would require restudy of the original material. Removal of the amber Hyalomma record means that the oldest fossil constraint for the five derived metastriate tick genera listed above is the subfossil D. reticulatus mentioned by Kulczyński in Schille (1916) from the ear of an extinct rhinoceros. Its ca. $1 \mathrm{Ma}$ age is clearly much too young for realistically dating when the genus evolved and means that we must currently rely on molecular clock methods to estimate cladogenesis dates for Haemaphysalis, Dermacentor, Hyalomma, Rhipicephalus and Boophilus.

\section{Palaeobiogeography}

A last point of interest is the fact that Southeast Asia has a complex geological history (e.g. Heine and Müller, 2005; Metcalfe, 2011, 2013; Seton et al. 2012). The region containing modern Myanmar was originally interpreted as having been part of the so-called Sibumasu terrane, which is thought to have rifted from the northern (i.e. Australian) part of Gondwana in the late Palaeozoic/early Mesozoic and collided with the Indochina plate by the Late Cretaceous. This led to a hypothesis that Burmese amber arthropods could have arrived in Asia by rafting across the Sibumasu terrane from Australia; see e.g. Dunlop and de Bernardi (2014) for a scenario along these lines involving an opilioacarid mite. A challenge to this hypothesis is the fact that back when the Sibumasu terrane is thought to have rifted from Gondwana (creating the MesoTethys Ocean), the landmass may actually have been covered by shallow seas. Also, much of Australia at this time was thought to have been covered in ice, and Sibumasu was still linked to Gondwana via the Lhasa block, Argoland and South West Borneo blocks (see e.g. Metcalfe, 2011). If this model is correct, the survival of terrestrial arthropods on the Sibumasu terrane after separation from Australia seems unlikely.

More recently, the area containing the source of Burmese amber has been interpreted as having been on the West Burma terrane instead; see Broly et al. (2015: Fig. 1) for a map of how the various elements may have accreted together to form modern 
Myanmar. As discussed for a Burmese amber spider by Selden et al. (2016), one hypothesis is that the West Burma terrane rifted from northern Australia in the Late Jurassic at ca. $156 \mathrm{Ma}$, and collided with the Sibumasu terrain the Late Cretaceous at about $80 \mathrm{Ma}$. In this scenario, at the time of amber deposition (ca. $99 \mathrm{Ma}$ ) the fauna would have been on an island which had been separated from Australia for about 75 million years. However, Metcalfe (2013) provided evidence for a much earlier (Devonian) separation from Australia and an earlier (Jurassic) collision of the West Burma terrane with Eurasia. In this model the Burmese amber fauna could potentially have arrived from Eurasia at some time between the Jurassic and the mid-Cretaceous.

With respect to ticks, Klompen et al. (1996) argued that basal taxa among both prostriate and metastriate ticks predominantly come from Australia today, which could imply that at least the Ixodidae have their origins here. Given that modern Amblyomma are strongly associated with a Gondwanan distribution (see above) it would be instructive to compare estimated dates of cladogenesis with some of these dates for major events in palaeobiogeography (see also Mans et al. 2012: Fig. 4). Caution is needed in dating ancient geographical splits between continents, and complete physical separation of landmasses may postdate the start of a split by a considerable period of time. Upchurch (2008) reviewed several competing models for Gondwana albeit with a focus on fossil vertebrates - and recognized four potential scenarios. In the Samafrica model, West Gondwana (South America + Africa) separated from East Gondwana (Antarctica, Australia and Indo-Madagascar) during the midJurassic (perhaps ca. $180 \mathrm{Ma}$ ). This seems to be the most widely accepted scenario; see also Gibbons et al. (2013) for example. In the Africa-first model, Africa separated from the rest of Gondwana during the Cretaceous while South America was still in contact with East Gondwana until the Late Cretaceous. In the multistage scenario elements of the previous hypotheses are combined, and in the Pan-Gondwana hypothesis the southern continents were still connected, at least at their southern tips, until the Late Cretaceous; perhaps as late as $80 \mathrm{Ma}$.

If the Samafrica model is correct, current molecular estimates for the Cretaceous radiation of the metastriate ticks (Fig. 3) postdate the Jurassic dissolution of Gondwana into an eastern and western province. Genera such as Amblyomma may show a Gondwanan distribution today, but current estimates of their origination dates correspond to a time in which Gondwana may have already separated into what would become the modern continents. In this hypothesis, either the molecular dates are too young, or modern patterns of biogeography have to be explained by alternative mechanisms. Furthermore, we still have to explain the presence of Amblyomma in the Cretaceous of Southeast-Asia. If its origins are Gondwanan, then the northern route was potentially closed by the breakup of Pangaea and the separation of Gondwana from Laurasia as early as ca. $220 \mathrm{Ma}$. If its ancestors rafted from Australia on the West Burma terrane, then in Metcalfe's (2013) model the rafting lineage must have separated from the Australian tick fauna around 360-420 million years ago. This seems highly unlikely as it would require these animals to have radiated into modern genera back in the Devonian, which significantly predates the Late Carboniferous molecular estimates (see above) of tick origins.

A final possibility is that Amblyomma actually originated in Eurasia - again perhaps during the Cretaceous as part of this metastriate radiation and arrived (and was fossilized) in the West Burma region via a northern route long after it had collided with Asia. As noted above, Upchurch's (2008) scenarios for the dissolution of Gondwana are largely based on fossil vertebrate data. However, there are numerous examples of plants and animals distributed both in former Gondwanan regions and (often as fossils) in the northern hemisphere. Examples include palpimanoid spiders (Wood et al. 2013, and references therein), ants (Zryanin, 2015), hemipterans (Szwedo et al. 2015), neuropterans (Wedmann and Makarkin, 2007) and branchiopod crustaceans (Korovchinsky, 2006; Van Damme and Sinev, 2013). The implication here is that these groups were once globally distributed across both the northern and southern continents, but at some stage (perhaps in response to glaciation) either became extinct in the north and/or migrated south. This has been referred to as the ousted relicts (Eskov and Golovatch, 1986) or ejected relicts (Korovchinsky, 2006) hypothesis. Such a scenario should also be borne in mind when considering how Amblyomma came to be so widespread in the former Gondwana region today: did it really originate here, or is it a relict of a once much wider distribution? A final thought is that several species of Amblyomma parasitize birds today, in which case trans-oceanic dispersal through flight remains a possibility.

\section{ACKNOWLEDGEMENTS}

We thank Jörg Wunderlich (Hirschberg) for making this material available for study, Lorenza Beati Ziegler (Georgia Southern University) for initial comments on the specimen, Ekaterina Sidorchuk (Borissiak Paleontological Institute) for drawing our attention to misidentifications in the literature and Martin Pfeffer and two anonymous reviewers for helpful comments on the manuscript.

\section{FINANCIAL SUPPORT}

This research received no specific grant from any funding agency, commercial or not-for-profit sectors. 


\section{REFERENCES}

Barker, S. C. and Murrell, A. (2004). Systematics and evolution of ticks with a list of valid genus and species names. Parasitology 129, 15-36. Beati, L. and Keirans, J. E. (2001). Analysis of the systematic relationships among ticks of the genera Rhipicephalus and Boophilus (Acari: Ixodidae) based on mitochondrial $12 \mathrm{~S}$ ribosomal DNA gene sequences and morphological characters. Fournal of Parasitology 87, 32-48. Black, W. C., IV and Piesman, J. (1994). Phylogeny of hard- and soft-tick taxa (Acari: Ixodida) based on mitochondrial 16S rDNA sequences. Proceeding of the National Academy of Science 91, 10034-10038.

Broly, P., Maillet, S. and Ross, A. J. (2015). The first terrestrial isopod (Crustacea: Isopoda: Oniscidea) from Cretaceous Burmese amber of Myanmar. Cretaceous Research 55, 220-228.

de la Fuente, J. (2003). The fossil record and the origin of ticks (Acari: Parasitiformes: Ixodida). Experimental and Applied Acarology 29, 331-344. Dobson, S. J. and Barker, S. C. (1999). Phylogeny of the hard ticks (Ixodidae) inferred from 18S rRNA indicates that the genus Aponomma is paraphyletic. Molecular Phylogenetics and Evolution 11, 288-295.

Dunlop, J. A. and de Bernardi, L. F. O. (2014). An opilioacarid mite in Cretaceous Burmese amber. Naturwissenschaften 101, 759-763.

Dunlop, J. A., Apanaskevich, D. A., Lehmann, J., Hoffmann, R., Fusseis, F., Ehlke, M., Zachow, S. and Xiao, X. (2016). Microtomography of the Baltic amber tick Ixodes succineus reveals affinities with the modern Asian disease vector Ixodes ovatus. BMC Evolutionary Biology 16, 203.

Eskov, K. Y. and Golovatch, S. I. (1986). On the origin of trans-Pacific disjunctions. Zoologische fahrbücher. Abteilung für Systematik, Geographie und Biologie der Tiere 113, 265-285.

Gibbons, A. D., Whittaker, J. M. and Müller, R. D. (2013). The breakup of East Gondwana: assimilating constraints from Cretaceous ocean basins around India into a best-fit tectonic model. Fournal of Geophysical Research 118, 808-822.

Grimaldi, D. A., Engel, M. S. and Nascimbene, P. C. (2002). Fossiliferous Cretaceous amber from Myanmar (Burma): its rediscovery, biotic diversity, and paleontological significance. American Museum Novitates 3361, 1-71. Guglielmone, A. A. and Nava, S. (2014). Names for Ixodidae (Acari: Ixodoidea): valid, synonyms, incertae sedis, nomina dubia, nomina nuda, lapsus, incorrect and suppressed names - with notes on confusions and misidentifications. Zootaxa 3767, 1-256.

Guglielmone, A. A., Robbins, R. G., Apanaskevich, D. A., Petney, T. N., Estrada-Peña, A. and Horak, I. G. (2014). The Hard Ticks of the World (Acari: Ixodida: Ixodidae). Springer, Berlin.

Heine, C. and Müller, R. (2005). Late Jurassic rifting along the Australian North West Shelf: margin geometry and spreading ridge configuration. Australian Fournal of Earth Sciences 52, 27-39.

Helm, O. (1894). Mittheilungen über Bernstein. XVI. Ueber Birmit, ein in Oberbirma vorkommendes fossiles Harz. Schriften der Naturforschenden Gesellschaft in Danzig, N.F. 8, 63-66.

Hoogstraal, H. (1985). Argasid and nuttalliellid ticks as parasites and vectors. Advances in Parasitology 24, 135-238.

Hoogstraal, H. and Aeschlimann, A. (1982). Tick-host specificity. Bulletin de la Société entomologique suisse 55, 5-32.

Keirans, J. E., Lane, R.S. and Cauble, R. (2002). A series of larval Amblyomma species (Acari: Ixodidae) from amber deposits in the Dominican Republic. International Fournal of Acarology 28, 61-66.

Klompen, H. and Grimaldi, D. (2001). First Mesozoic record of a parasitiform mite: a larval argasid tick in Cretaceous amber (Acari: Ixodida: Argasidae). Annals of the Entomological Society of America 94, 10-15.

Klompen, H., Dobson, S. J. and Barker, S. C. (2002). A new subfamily, Bothriocrotoninae n. subfam., for the genus Bothriocroton Keirans, King \& Sharrad, 1994 status amend. (Ixodida: Ixodidae), and the synonymy of Aponomma Neumann, 1899 with Amblyomma Koch, 1844. Systematic Parasitology 53, 101-107.

Klompen, J. S. H., Black, W. C., IV, Keirans, J. E. and Oliver, J. H., Jr. (1996). Evolution of ticks. Annual Reviews of Entomology 41, 141-161.

Klompen, J. S. H., Black, W. C., IV, Keirans, J. E. and Norris, D. E. (2000). Systematics and biogeography of hard ticks, a total evidence approach. Cladistics 16, 79-102.

Korovchinsky, N. M. (2006). The Cladocera (Crustacea: Branchiopoda) as a relict group. Zoological Fournal of the Linnaean Society 147, 109-124. Lane, R. S. and Poinar, G. O., Jr. (1986). First fossil tick (Acari: Ixodidae) in new world amber. International fournal of Acarology 12, 75-78.

Limaye, A. (2012). Drishti-volume exploration and presentation tool. In SPIE Proceedings, 8506, 85060X, JOUR. Retrieved from http://dx.doi.org/ $10.1117 / 12.935640$.
Mans, B. J., de Klerk, D., Pienaar, R., Castro, M. H. and Latif, A. A. (2012). The mitochondrial genomes of Nuttalliella namaqua (Ixodoidea: Nuttalliellidae) and Argas africolumbae (Ixodoidea: Argasidae): estimation of divergence dates for the major tick lineages and reconstruction of ancestral blood-feeding characteristics. PLoS ONE 7(11), e4946.

Metcalfe, I. (2011). Palaeozoic-Mesozoic history of SE Asia. In The SE Asian Gateway: History and Tectonics of the Australia-Asia Collision Vol. 355 (ed. Hall, R., Cottam, M. A. and Wilson, M. E. J.), pp. 7-35. Geological Society of London, London.

Metcalfe, I. (2013). Gondwana dispersion and Asian accretion: tectonic and palaeogeographic evolution of eastern Tethys. Fournal of Asian Earth Sciences 66, 1-33.

Nava, S., Guglielmone, A. A. and Mangold, A. J. (2009). An overview of systematics and evolution of ticks. Frontiers in Bioscience 14, 2857-2877. Nicholson, W. L., Sonenshine, D. E., Lane, R. S. and Uilenberg, G. (2009). Ticks (Ixodida). In Medical and Veterinary Entomology, 2nd Edn (ed. Mullen, G. R. and Durden, L. A.), pp. 493-542. Academic Press, New York.

Oliver, J. H., Jr. (1989). Biology and systematics of ticks (Acari: Ixodida). Annual Reviews of Ecology and Systematics 20, 397-430.

Poinar, G. O., Jr. (1995). First fossil soft tick, Ornithodoros antiquus n. sp. (Acari: Argasidae) in Dominican amber with evidence of their mammalian host. Experimentia Basel 51, 584-587.

Poinar, G. O., Jr. and Brown, A. E. (2003). A new genus of hard ticks in Cretaceous Burmese amber (Acari: Ixodida: Ixodidae). Systematic Parasitology 54, 199-205.

Poinar, G. O., Jr. and Buckley, R. (2008). Compluriscutula vetulum (Acari: Ixodida: Ixodidae), a new genus and species of hard tick from Lower Cretaceous Burmese amber. Proceedings of the Entomological Society of Washington 110, 445-450.

Sanchez, J.P., Nava, S., Lareschi, M., Ortiz, P.E. and Guglielmone, A. A. (2010). Finding of an ixodid tick inside a Late Holocene owl pellet from northwestern Argentina. Fournal of Parasitology 96, 820-822.

Schille, F. (1916). Entomologie aus der Mammut- und Rhinoceros-Zeit Galiziens. Entomologische Zeitschrift 30, 42-43.

Selden, P. A., Zhang, W. and Ren, D. (2016). A bizarre armoured spider (Araneae: Tetrablemmidae) from Upper Cretaceous Myanmar amber. Cretaceous Research 66, 129-135.

Seton, M., Müller, R.D., Zahirovic, S., Gaina, C., Torsvik, T., Shephard, G., Talsma, A., Gurnis, M., Turner, M., Maus, S. and Chandler, M. (2012). Global continental and ocean basin reconstructions since $200 \mathrm{Ma}$. Earth Science Reviews 113, 212-270.

Shi, G.-H., Grimaldi, D. A., Harlow, G. E., Wang, J., Yang, M.-C., Lei, W.-Y., Li, Q. and Li, X.-H. (2012). Age constraints on Burmese amber based on U-Pb dating of zircons. Cretaceous Research 37, 155-163. Sonenshine, D. and Roe, R. M. (eds) (2013). Biology of Ticks, 2nd Edn. Bands 1-2. Oxford University Press, Oxford.

Szwedo, J., Stroiński, A. and Lin, Q. (2015). Tip of the clade on the top of the World - the first fossil Lophopidae (Hemiptera: Fulgoromorpha) from the Palaeocene of Tibet. Naturwissenschaften 102, 1-16.

Upchurch, P. (2008). Gondwanan break-up: legacies of a lost world? Trends in Ecology and Evolution 23, 229-236.

Van Damme, K. and Sinev, A. Y. (2013). Tropical Amphi-Pacific disjunctions in the Cladocera (Crustacea: Branchiopoda). Fournal of Limnology 72, 1-36.

Voltzit, O. V. (2007). A review of Neotropical Amblyomma species (Acari, Ixodida, Ixodidae). Acarina 15, 3-134.

Voltzit, O. V. and Keirans, J. E. (2002). A review of Asian Amblyomma species (Acari, Ixodida, Ixodidae). Acarina 10, 95-136.

Voltzit, O. V. and Keirans, J. E. (2003). A review of African Amblyomma species (Acari, Ixodida, Ixodidae). Acarina 11, 135-214.

Wedmann, S. and Makarkin, V. N. (2007). A new genus of Mantispidae (Insecta: Neuroptera) from the Eocene of Germany, with a review of the fossil record and palaeobiogeography of the family. Zoological Fournal of the Linnean Society 149, 701-716.

Weidner, H. (1964). Eine Zecke, Ixodes succineus sp. n. im Baltischen Bernstein. Veöffentlichungen aus dem Überseemuseum Bremen 3, 143-151.

Wood, H. M., Matzke, N. J., Gillespie, R. G. and Griswold, C.E. (2013). Treating fossils as terminal taxa in divergence time estimation reveals ancient vicariance patterns in the palpimanoid spiders. Systematic Biology 62, 264-284.

Zryanin, V. A. (2015). The first subterranean ant species of the genus Meranoplus F. Smith, 1853 (Hymenoptera: Formicidae) from Vietnam. Caucasian Entomological Bulletin 11, 153-160. 